$$
\text { JEKK } \quad \begin{gathered}
\text { Jurnal Epidemiologi Kesehatan Komunitas } \\
3(1), 2018,48-53
\end{gathered}
$$

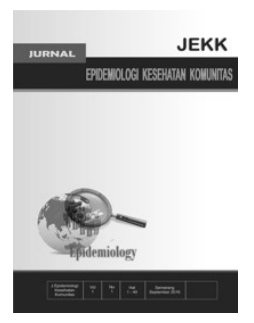

\title{
Faktor-Faktor yang Berpengaruh terhadap Kejadian Tuberkulosis pada Wanita (Studi Kasus di RSUD Kabupaten Brebes)
}

\author{
Muslih $^{*}$, Djoko Tri Hadi Lukmono ${ }^{* *}$, Suhartono ${ }^{* * *}$, Ari Suwondo ${ }^{* * *}$, Martini $^{* * * *}$ \\ ${ }^{*}$ RSUD Kabupaten Brebes, ${ }^{* *}$ Fakultas Kedokteran Universitas Diponegoro, ${ }^{* * *}$ Fakultas \\ Kesehatan Masyarakat Universitas Diponegoro
}

\begin{abstract}
Background: Tuberculosis (TB) risk in women increased during the productive age. Various problems can arise if a woman suffering from TB given the role of women, especially married, pregnant, and have children. Her role as a housewife who must carry out the task of physical and mental care of children at the same time taking care of her husband will be disrupted. To determine the chances of marital status, pregnancy, parity, physical activity, level of education, level of knowledge, the kitchen smoke pollution, household contact history, history of comorbidities DM, population density, and spacious house ventilation of TB incidence in women.

Methods: The study was observational analytic study with case control design. The sample size is as much as 128 people, consisting of 64 cases and 64 controls. Sampling was done by proportional random sampling technique. Data were analyzed with univariable, bivariable, and multivariable.

Results: The results of multivariate analysis, parity (OR 5.9, 95\% CI 2.40-14.89, p 0.0001), contact history (OR 4.9, 95\% CI 1.75-14.14, p 0.003), pollution kitchen smoke (OR 4.2, 95\% CI 1.71-10.67, p 0.002), ventilation (OR 4.2, 95\% CI 1.72- 10.44, p 0.002) as a risk factor for TB in women.

Conclusion: The incidence of tuberculosis in women in Brebes chance or greater risk in women with high parity, a history of contacts, exposure to cooking smoke pollution is high and stay at home with ventilation that do not qualify health requirements.
\end{abstract}

Keywords: tuberculosis; women; risk factors

*Penulis korespondensi : muslih3009@gmail.com 
Tuberkulosis (TB) merupakan penyebab kematian pertama pada orang dewasa di negara berkembang. Tuberkulosis (TB) adalah penyakit infeksi yang disebabkan oleh bakteri Mycobacterium tuberculosis (M.tb) kadang disebabkan oleh Mycobacterium bovis dan africanun yang pada umumnya menyerang paru dan sebagian menyerang di luar paru, seperti kelenjar getah bening, kulit, usus/saluran pencernaan, selaput otak, dan sebagainya. ${ }^{1,2}$ Organisme ini disebut pula sebagai basil tahan asam (BTA).

Tahun 2010 sebanyak 6,2 juta orang di dunia telah didiagnosis menderita TB terdiri dari 5,4 juta kasus baru, 300.000 kasus kambuh dan 400.000 pengobatan ulang. Negara-negara yang memiliki beban tinggi penyakit TB (high burden countries) sebanyak 22 negara termasuk Indonesia menyumbang sekitar $82 \%$ penderita TB dunia. ${ }^{3}$ Kasus TB di dunia menurut laporan WHO tahun 2010, total kasus baru BTA positif sebanyak 2.591.032 dengan proporsi pada laki-laki lebih tinggi dibandingkan pada wanita yaitu sebesar $65 \%{ }^{2}$ menderita TB dan kematian akibat TB pada sebagian besar negara di dunia, lebih banyak terjadi pada pria daripada wanita. Namun TB merupakan penyebab kematian dari golongan penyakit infeksi pada wanita. Setiap tahun, sekitar 700.000 wanita meninggal karena $\mathrm{TB}$, dan lebih dari tiga juta terkena TB. Dampak TB pada wanita terutama secara ekonomi dan reproduksi, serta berdampak terhadap anak dan anggota keluarga yang lain.

Di Indonesia menurut WHO pada tahun 2011 jumlah insiden kasus TB paru sebesar 222 per 1000.000 penduduk, prevalensi sebesar 489 per 100.000 penduduk dan kematian sebesar 48 per 100.000 penduduk. $^{3}$ Pada tahun 2012, insiden kasus TB paru menduduki peringkat keempat di dunia. Kasus TB di Indonesia tahun 2011 tercatat sebanyak 316.562 kasus dengan kasus berdasarkan jenis kelamin adalah 182.853 kasus $(57,8 \%)$ pada pria dan 133.709 kasus $(42,2 \%)$ pada wanita. Khusus kasus TB BTA positif tahun 2011 tercatat 194.780 kasus, sebanyak 115.450 kasus $(59,3 \%)$ pada pria dan 79.330 kasus (40,7\%) pada wanita.

Penyebab perbedaan prevalensi TB berdasarkan jenis kelamin, belum dapat dipastikan. Perbedaan ini kemungkinan disebabkan oleh adanya perbedaan dalam faktor risiko infeksi, tingkat perkembangan dari infeksi menjadi penyakit, rendahnya pelaporan kasus TB pada wanita atau perbedaan akses pelayanan. $^{5}$ Belum banyak penelitian tentang faktor risiko kejadian TB paru pada wanita. Berbagai faktor yang dididuga berhubungan dengan kejadian TB paru pada wanita yaitu status perkawinan, kehamilan, paritas, riwayat penyerta DM, aktifitas fisik, tingkat pendidikan, pengetahuan, riawayat kontak, polusi asap dapur, kepadatan hunian, dan luas ventilasi. Berbagai masalah akan muncul jika wanita menderita $\mathrm{TB}$, mengingat peran wanita terutama yang sudah menikah, hamil, dan memiliki anak. Perannya sebagai seorang ibu rumah tangga yang harus melaksanakan tugas pengasuhan fisik maupun mental anak-anak sekaligus mengurus suami akan terganggu.

\section{Metode}

Penelitian ini merupakan penelitian observasional analitik dengan metode penelitian kasus kontrol (case-control). Penelitian dengan desain kasus kontrol ditujukan untuk mengkaji hubungan antara efek tertentu dengan faktor risiko tertentu. Kasus adalah pasien wanita yang menderita tuberkulosis yang pernah atau sedang rawat inap atau rawat jalan terhitung tahun 2015 di RSUD Kabupaten Brebes berdasarkan diagnosa dan atau hasil pemeriksaan laboratorium positif dan foto rontgen. Sedangkan kontrol adalah 
pasien wanita yang tidak menderita tuberkulosis yang pernah melakukan pemeriksaan tuberkulosis terhitung tahun 2015 di RSUD Kabupaten Brebes berdasarkan diagnosa hasil pemeriksaan laboratoriun negatif dan foto rontgen.

Penelitian dilaksanakan pada bulan Mei-Juli 2016. Besar sampel dalam penelitian ini adalah 64 kasus dan 64 kontrol dan metode pengambilan sampel yang digunakan adalah dengan cara proporsional random sampling yaitu pengambilan sampel sedemikian rupa terhadap populasi yang terdapat dalam sub-sub populasi dalam penelitian ini adalah yang berobat di RSUD Kabupaten Brebes dengan ketentuan bahwa setiap anggota populasi mempunyai kesempatan yang sama untuk diambil sebagai sampel.
Variabel terikat dalam penelitian ini adalah kejadian TB paru pada wanita dan variabel bebas dalam penelitian ini terdiri dari status perkawinan, kehamilan, paritas, riwayat penyerta DM, aktifitas fisik, tingkat pendidikan, tingkat pengetahuan, riwayat kontak, polusi asap dapur, kepadatan hunian, dan luas ventilasi. Pengolahan dan analisis data dilakukan dengan system komputer program SPSS for window terdiri dari analisis univariat, bivariat dan multivariat.

\section{Hasil}

Gambaran umum karakteristik responden baik kelompok kasus maupun kontrol meliputi umur dan tingkat pendidikan yang disajikan pada Tabel 1 .

Tabel 1. Distribusi Responden Menurut Umur dan Tingkat Pendidikan.

\begin{tabular}{|c|c|c|c|c|c|}
\hline & \multicolumn{4}{|c|}{ TB paru Pada Wanita } \\
\hline & & \multicolumn{2}{|c|}{ Kasus } & \multicolumn{2}{|c|}{ Kontrol } \\
\hline & & \multirow[t]{2}{*}{$\mathrm{f}$} & \multirow[t]{2}{*}{$\%$} & \multirow[t]{2}{*}{$\mathrm{f}$} & \multirow[t]{2}{*}{$\%$} \\
\hline \multicolumn{2}{|c|}{ 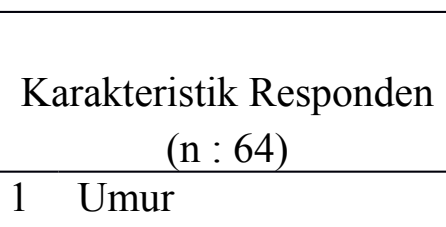 } & & & & \\
\hline & Mean & 37.31 & & 34,95 & \\
\hline & Median & 35 & & 33 & \\
\hline & Modu & 35 & & 33 & \\
\hline & Minimum & 20 & & 21 & \\
\hline & Maximum & 62 & & 57 & \\
\hline \multirow[t]{6}{*}{2} & Tingkat Pendidikan & & & & \\
\hline & Tidak Tamat SD & 2 & 3,1 & 3 & 4,7 \\
\hline & Tamat SD & 24 & 37,5 & 21 & 32,8 \\
\hline & Tamat SMP & 15 & 23,4 & 13 & 20,3 \\
\hline & Tamat SMA & 23 & 35,9 & 24 & 37,5 \\
\hline & Perguruan Tinggi & - & - & 3 & 4,7 \\
\hline
\end{tabular}

Berdasarkan data Tabel 1. diketahui bahwa distribusi umur responden pada kelompok kasus rata-rata umurnya 37,31 tahun, nilai tengah umur 35 tahun, umur paling banyak 35 tahun umur terendah 20 tahun dan umur tertinggi 62 tahun. Pada kelompok kontrol rata-rata umurnya yaitu 34,95 tahun, nilai tengahnya umur 33, umur paling banyak 33 tahun, umur terendah 21 tahun dan umur tertinggi 57 tahun. Tingkat pendidikan responden pada kelompok kasus paling banyak tamat SD dan tamat SMA (37,5\% dan 35,9\%) sedangkan pada kelompok kontrol tamat SMA dan tamat SD $(37,5 \%$ dan $32,8 \%)$ namun tamat perguruan tinggi lebih 
banyak pada kelompok kontrol $(4,7 \%)$ dibandingkan pada kelompok kasus sebanyak $0 \%$.

Dari analisis bivariat, didapatkan hasil bahwa sebanyak 6 variabel sebagai faktor risiko terhadap kejadian TB paru pada wanita yaitu paritas, aktifitas fisik, riwayat kontak, polusi asap dapur, kepadatan hunian dan luas ventilasi. Hasil analisis bivariat disajikan dalam Tabel 2

Tabel 2. Rangkuman hasil analisis bivariat faktor risiko kejadian TB paru pada wanita.

\begin{tabular}{llccc}
\hline & Faktor Kejadian TB paru pada Wanita & OR & $95 \%$ CI & p Value \\
\hline 1. & Paritas $>2$ & 1,1 & $0,55-2,38$ & 0,0001 \\
2. & Polusi asap dapur & 1,9 & $0,75-5,06$ & 0,0001 \\
3. & Luas ventilasi & 4,5 & $2,14-9,51$ & 0,001 \\
4. & Riwayat kontak & 1,2 & $0,51-2,78$ & 0,001 \\
5. & Aktifitas fisik berat & 3,0 & $1,39-6,68$ & 0,004 \\
6. & Kepadatan hunian & 1,3 & $1,63-2,65$ & 0,022 \\
7. & Keadaan hamil & 1,5 & $0,77-3,26$ & 0,160 \\
8. & Tingkat pengetahuan & 4,1 & $1,76-9,91$ & 0,203 \\
9. & Tingkat pendidikan & 4,1 & $1,93-8,72$ & 0,469 \\
10. & Riwayat penyakit penyerta DM & 2.2 & $1,12-4,62$ & 0,669 \\
11. & Status perkawinan & 3,4 & $1,64-7,03$ & 0,710 \\
\hline
\end{tabular}

Dari analisis di atas kemudian dilakukan analisis regresi logistik untuk mengetahui variabel yang menjadi prediktor terjadinya TB paru pada wanita. Variabel yang dijadikan kandidat dalam uji regresi logistik ini adalah variabel dari hasil uji chi square dengan nilai $\mathrm{p}<0,25$. Ada 8 variabel yang masuk dalam kandidat analisis regresi logistik, yaitu paritas $>2$, aktifitas fisik berat, tingkat pengetahuan kurang, ada riwayat kontak, polusi asap dapur tinggi, kepadatan hunian, luas ventilasi, dan keadaan hamil. Rangkuman hasil analisis multivariat disajikan dalam Tabel 3.

Tabel 3. Hasil analisis model akhir Uji Multiple Logistic Regression faktor risiko kejadian TB paru pada wanita.

\begin{tabular}{|c|c|c|c|}
\hline Faktor Risiko Kejadian TB paru & $\mathrm{B}$ & $95 \% \mathrm{CI}$ & $\operatorname{Exp}(\mathrm{B}) / \mathrm{aOR}$ \\
\hline 1. Paritas & 1,789 & $2,40-14,89$ & 5,9 \\
\hline Riwayat kontak & 1,606 & $1,75-14,14$ & 4,9 \\
\hline 3. Polusi asap dapur & 1,452 & $1,71-10,67$ & 4,2 \\
\hline 4. Luas ventilasi & 1,444 & $1,72-10,44$ & 4,2 \\
\hline Constant & $-2,535$ & & \\
\hline
\end{tabular}

Hasil analisis model akhir dengan kemaknaan nilai OR pada 95\%CI, diperoleh hasil bahwa paritas $>2$ berisiko 5,9 kali lebih besar menderita TB paru dibandingkan dengan wanita paritas $<=2$. Riwayat kontak dengan penderita TB paru berisiko 4,9 kali lebih besar menderita TB paru dibandingkan dengan yang tidak ada 
riwayat kontak dengan penderita TB paru. Polusi asap dapur dengan tingkat keterpaparan yang tinggi berisiko 4,2 kali lebih besar menderita TB paru dibandingkan dengan polusi asap dapur dengan tingkat keterpaparan rendah. Wanita yang tinggal di rumah dengan luas ventilasi yang tidak memenuhi syarat

Hasil analisis regresi logistik menunjukkan bahwa wanita di Kabupaten Brebes dengan paritas tinggi $(>2)$ berpeluang 4,5 kali lebih besar untuk menderita TB paru dibandingkan wanita paritas rendah $(<=2)$ dan secara statistik bermakna. Hasil penelitian ini sejalan dengan penelitian King et $a l^{6}$. di Hongkong dan Sumarna et $a l^{7} \mathrm{di}$ kabupaten Cilacap. Masalah lain akan muncul ketika seorang wanita sakit terutama yang sudah kawin dan mempunyai anak. Dampak jika wanita yang sakit selain terhadap dirinya juga berdampak kepada suami dan anaknya, terlebih jika wanita tersebut memiliki jumlah anak yang banyak. Sejumlah peneliti telah mengamati bahwa ketika perempuan sakit mereka menunggu lebih lama untuk melaporkan penyakit mereka dari pada pria. Wanita yang sakit cenderung mengabaikan penyakit mereka sendiri sampai sangat mengganggu mereka kegiatan sehari-hari. Hal ini memiliki konsekuensi serius bagi anggota keluarga lainnya. ${ }^{6,7}$

Hasil analisis regresi logistik menunjukkan bahwa wanita di Kabupaten Brebes yang memiliki riwayat kontak dengan penderita TB paru dewasa berpeluang 4,1 kali lebih besar untuk menderita TB paru dibandingkan dengan wanita yang tidak memiliki riwayat kontak dengan penderita TB paru dewasa dan secara statistik bermakna. Hasil ini sejalan dengan teori bahwa penderita TB paru BTA positif merupakan sumber penular langsung. Kontak serumah memungkinkan seseorang berada dekat dengan penderita TB sehingga akan makin berisiko 4,2 kali lebih besar menderita TB paru dibandingkan dengan wanita yang tinggal di rumah dengan luas ventilasi yang memenuhi syarat. Probalilitas keempat faktor risiko tersebut untuk menyebabkan TB paru yaitu sebesar $97,8 \%$.

banyak dosis TB yang mungkin akan terhirup oleh kontak. Hasil penelitian sejalan dengan penelitian ini dikemukakan oleh Susilawati et $a l^{12}$ menyebutkan bahwa faktor risiko kontak serumah dengan penderita TB BTA positif diperoleh nilai $O R$ 5,413, CI 95\% 2,29312,774, p-value 0,000. Kontak terdekat dengan penderita TB paru adalah orang yang berbagi ruang udara yang sama dalam rumah tangga atau lingkungan tertutup lain dalam waktu yang lama yaitu anggota keluarga yang tinggal bersama. ${ }^{10-}$ 12

Hasil analisis regresi logistik menunjukkan bahwa wanita di Kabupaten Brebes yang terpapar asap dapur dengan intensitas tinggi berpeluang 4,1 kali lebih besar untuk menderita TB paru dibandingkan wanita yang terpapar asap dapur dengan intensitas rendah dan secara statistik bermakna. Menurut teori bahwa penggunaan bahan bakar biomassa salah satunya kayu bakar sebagai sumber dasar kebutuhan energy kehidupan sehari-hari terutama pada rumah tangga untuk keperluan memasak menimbulkan kekhawatiran karena emisi polutan dari pembakaran bahan bakar padat dapat menghasilkan polutan udara termasuk organik, anorganik, dan partikel. Asap dapur mengandung zat berbahaya seperti karbon dioksida $\left(\mathrm{CO}_{2}\right)$, sulfur dioksida $\left(\mathrm{SO}_{2}\right)$, dan nitrogen dioksida $\left(\mathrm{NO}_{2}\right)$, yang bersifat iritan terhadap saluran pernafasan dan dan menyebabkan kadar $\mathrm{O}_{2}$ di paruparu berkurang sehingga riskan terhadap masuknya berbagai kuman penyakit ke paru-paru terutama Mycobacterium 
tuberculosis yang merupakan penyebab TB paru. ${ }^{14-17}$

Hasil analisis regresi logistik menunjukkan bahwa wanita di Kabupaten Brebes yang tinggal di rumah dengan ventilasi yang tidak memenuhi syarat kesehatan berpeluang 3,4 kali lebih besar untuk menderita TB paru dibandingkan wanita yang tinggal di rumah dengan ventilasi yang memenuhi syarat kesehatan dan secara statistik bermakna. Hasil ini sesuai dengan hasil penelitian Ma'arif et al. dan Simbolon et al yang menyimpulkan bahwa rumah dengan ventilasi yang tidak memenuhi syarat berpengaruh terhadap kejadian TB paru BTA positif dibandingkan rumah dengan ventilasi yang memenuhi syarat. Fungsi ventilasi rumah adalah untuk sirkulasi pergantian udara dalam rumah sehingga basil Mycobacterium tuberculosis dan kuman lain terbawa keluar ruangan dan mati terkena sinar ultra violet. Fungsi lainnya adalah mengurangi kelembaban. Kelembaban dalam ruangan tertutup dimana banyak terdapat manusia di dalamnya lebih tinggi dibanding kelembaban di luar ruangan. Ventilasi yang baik adalah $10 \%$ dari luas lantai. ${ }^{18-19}$

Variabel yang diteliti namun tidak terbukti sebagai faktor risiko kejadian TB paru pada wanita yaitu status perkawinan, kehamilan, riwayat penyerta DM, aktifitas fisik, tingkat pendidikan, tingkat pengetahuan, dan kepadatan hunian. Keterbatasan dalam penelitian ini yaitu potensi terjadinya bias informasi karena data diambil secara retrospektif serta potensi terjadinya bias seleksi dalam pemilihan kasus dan kontrol.

\section{Kesimpulan}

Faktor yang terbukti merupakan faktor risiko kejadian TB paru pada wanita yaitu paritas $>2$, memiliki riwayat kontak, paparan polusi asap dapur, dan luas ventilasi yang tidak sesuai dengan syarat kesehatan. Sedangkan faktor yang tidak terbukti sebagai faktor risiko kejadi TB paru pada wanita yaitu status perkawinan, kehamilan, riwayat penyerta DM, aktifitas fisik, tingkat pendidikan, tingkat pengetahuan, dan kepadatan hunian.

\section{Ucapan Terimakasih}

Terimakasih kepada pihak RSUD Kabupaten Brebes yang telah memberikan ijin penelitian membantu dalam proses pengumpulan data.

\section{Daftar Pustaka}

1. Frieden, T. R., Sterling, T. R., Munsiff, S. S., Watt, C. J. \& Dye, C. (2003) Tuberculosis. Lancet, $362887-$ 899.

2. Kritski, A. \& Melo, F. A. F. d. (2007) Tuberculosis in adults. In: Palomino, J. C., Leão, S. C. \& Ritacco, V. (eds.). www.Tuberculosis Textbook.com.

3. WHO (2011) WHO Report 2011: Global tuberculosis control, Geneva, Swiss:WHO.

4. WHO (2013) Tuberculosis and gender.Available:

http://www.who.int/tb/challenges/gen der/page 1/en [Accessed 13-032103].

5. Crofton, J., Horne, N. \& Miller, F. (2002) Tuberkulosis klinis (terjemahan), Jakarta:Widya Medika.

6. Smith, I. (1994) Women and tuberculosis: gender issues and tuberculosis control in Nepal. Unpublished MPH Dissertation. Nuffield Institute for Health.

7. Kemenkes RI (2010) Hasil Riset Kesehatan Dasar 2010, Jakarta:Kemenkes RI.

8. Kemenkes RI (2012) Profil data kesehatan Indonesia tahun 2011, Jakarta:Kemenkes RI. 
9. RSUD Kabupaten Brebes (2014) Profil Kesehatan, Brebes : RSUD Brebes

10. Widoyono (2008) Penyakit tropis: epidemiologi, penularan, pencegahan dan pemberantasannya, Surabaya:Erlangga.

11. Kemenkes RI (2011) Pedoman nasional pengendalian tuberkulosis, Jakarta:Kemenkes RI.

12. Atmosukarto \& Soewasti (2000) Pengaruh lingkungan pemukiman dalam penyebaran Tuberkulosis. Media Litbangkes, 9(4).

13. Mahpudin, A. H. \& Mahkota, R. (2004) Faktor lingkungan fisik rumah, respon biologi dan kejadian TBC paru di Indonesia. JKMN, 1(4).

14. Putra, A. K. (2010) Kejadian Tuberkulosis pada anggota keluarga yang tinggal serumah dengan penderita TB paru BTA positif.

15. Hudelson, R. (1996) Review article Gender differentials in tuberculosis : the role of socio-economic and cultural factors. IUATLD, (October 1995): 391-400.

16. King, P. a., Duthie, S. J., Li, D. F. \& Ma, H. K. (1990) Obstetric outcome among Vietnamese refugees in Hong Kong: an age-matched casecontrolled study. International journal of gynaecology and obstetrics: the official organ of the International Federation of Gynaecology and Obstetrics, 33(3): 203-10.

17. Lemeshow, S., Hosmer, D., J, K. \& Lwanga, S. (1997) Besar sampel dalam penenlitian kesehatan:Gadjah Mada University Press.

18. Budiarto, E. (2002) Biostatistik untuk kedokteran dan kesehatan masyarakat, Jakarta:EGC.

19. Sumarna N (2013) Beberapa faktor risiko kejadian TB paru pada wanita di Kabupaten Cilacap Propinsi Jawa Tengah tahun 2013. 
